\title{
The effect of catch crop species on selenium availability for succeeding crops
}

\author{
Eleftheria Stavridou • Scott D. Young • \\ Kristian Thorup-Kristensen
}

Received: 23 April 2011 / Accepted: 25 July 2011 / Published online: 10 August 2011

(C) The Author(s) 2011. This article is published with open access at Springerlink.com

\begin{abstract}
Background and Aims Selenium (Se) is an essential nutrient for humans and animals. In order to ensure an optimal concentration of Se in crops, Se fertilisers are applied. Catch crops may be an alternative way to increase Se concentrations in vegetables.

Methods Three experiments in Denmark between 2007-10 investigated the ability of catch crops (Italian ryegrass, fodder radish and hairy vetch) under different fertiliser regimes to reduce soil Se content in the autumn and to increase its availability in spring to the succeeding crop.

Results and Conclusions The catch crops (Italian ryegrass and fodder radish) increased water-extractable
\end{abstract}

Responsible Editor: Fangjie Zhao.

E. Stavridou $(\varangle) \cdot K$. Thorup-Kristensen

Department of Food Science, University of Aarhus,

Kirstinebjergvej 10,

DK-5792 Aarslev, Denmark

e-mail: Eleftheria.Stavridou@agrsci.dk

S. D. Young

School of Biosciences, University of Nottingham,

Sutton Bonington Campus,

Loughborough, Leicestershire LE12 5RD, UK

Present Address:

K. Thorup-Kristensen

Faculty of Life Science, Department of Agriculture

and Ecology, University of Copenhagen,

Højbakkegård Alle 13,

DK-2630 Tåstrup, Denmark
Se content in the $0.25-0.75 \mathrm{~m}$ soil layer in only one of the experiments. Selenium uptake by the catch crops varied between 65 and $3263 \mathrm{mg} \mathrm{ha}^{-1}$, depending on species, year and fertilisation treatment; this corresponded to $0.1-3.0 \%$ of the water-extractable soil Se content. The influence of catch crops on $\mathrm{Se}$ concentrations and uptake in onions and cabbage was low. There was a decrease in Se uptake and recovery of applied Se by onions following catch crops, which might indicate Se immobilisation during catch crop decomposition.

Keywords Cover crops · Green manure · Mineralisation · Leaching · Onion · Cabbage

\section{Introduction}

Selenium (Se) is a naturally occurring element with chemical characteristics similar to sulphur (S). Selenium in plant products was initially known for its toxicity to animals (Moxon and Rhian 1943) but since the late 1950s $\mathrm{Se}$ has been recognised as an essential nutrient for animals and later for humans (Terry et al. 2000). Selenium concentrations in the soil are highly variable and mainly depend on the soil parent material. The concentrations range between 0.01 and $2.0 \mathrm{mg} \mathrm{Se} \mathrm{kg}{ }^{-1}$ in most soils, with a mean of $\sim 0.4 \mathrm{mg} \mathrm{kg}^{-1}$. However in seleniferous areas concentrations can be up to $1200 \mathrm{mg} \mathrm{Se} \mathrm{kg} \mathrm{m}^{-1}$ (White et al. 2007). The mean Se intake for the 
Danish population is $38-47 \mu \mathrm{g} \mathrm{Se} \mathrm{d}^{-1}$ (Rayman 2008), whereas the European population reference intake is $55 \mu \mathrm{g} \mathrm{Se} \mathrm{d}{ }^{-1}$ (EC Scientific Committe on Food 2003). Sub-optimal Se intake and status is associated with cardiovascular disease, myopathy, oxidative stress-related disorders, increased cancer risk and immune dysfunction (Rayman 2008).

Selenium enriched fertilisers are used to increase Se concentration in crops. Finland was the first country to establish a nationwide Se bio-fortification strategy (Eurola et al. 1991). However studies showed that only 7 to $35 \%$ of the applied Se was utilised by plants (Broadley et al. 2010; Eich-Greatorex et al. 2007), while the remaining Se may be retained in the soil or lost by leaching and volatilisation. In a simple leaching experiment losses were between 1 and $16 \%$ of the applied Se (Eich-Greatorex et al. 2007). Wang et al. (1994) showed that in Finland the Se fertilisers might have temporarily increased the Se concentration in river waters and headwater streams, by surface runoff of selenate after rainfall. However 6 years after the establishment of the nationwide Se fertilisation in Finland, Se concentrations in natural ground-waters and wells were below the health-based limit of $10 \mu \mathrm{g} \mathrm{L}^{-1}$ set for drinking water (Alfthan et al. 1995). The amount of Se lost through leaching depends on the form of Se present and its mobility, which is a function of soil $\mathrm{pH}$, the presence of competing ions (sulphate, phosphate, oxalate, and molybdate), climate and organic matter (Eich-Greatorex et al. 2007; Mayland et al. 1991). The predominant forms of Se available to plants are selenate and selenite. Selenate is highly mobile but selenite is strongly sorbed by hydrous ion oxides, clays and organic matter (Mayland et al. 1991). Selenate tends to be the predominant form in aerobic and neutral to alkaline environments, whereas selenite is the major form present in acid soils (Mayland et al. 1991).

Although the environmental risk from Se applied as fertiliser at an annual rate $<10 \mathrm{~g} \mathrm{ha}^{-1}$ is low, it is necessary to consider farming practices to utilise residual Se after harvest to minimise Se leaching. Little is known about how Se is affected by farming practices, or to what extent leaching of Se can be reduced by improved plant Se uptake and recirculation. Catch crops are widely used to improve nitrogen $(\mathrm{N})$ management and they have also been successfully used to reduce S leaching (Thorup-Kristensen et al. 2003). Furthermore after being incorporated into the soil, decomposition of the catch crop plant material leads to mineralisation of its $\mathrm{S}$, which is then utilised by the succeeding crops (Eriksen et al. 2004; Eriksen and Thorup-Kristensen 2002). The high S demand of Brassica crops efficiently depleted soil sulphate concentration (Eriksen and ThorupKristensen 2002). Due to chemical similarities with sulphate, selenate is taken up through high affinity sulphate transporters and follows the same assimilation pathways as $\mathrm{S}$ in plants (Terry et al. 2000). Understanding how agronomic management and crop rotation may affect Se leaching loss or its availability for crops is lacking. We do not know how effective catch crops will be in (i) reducing $\mathrm{Se}$ leaching losses and (ii) recycling Se to make it available for succeeding crops. A better understanding of these processes is important both in low $\mathrm{Se}$ environments where we want to improve the utilization of limited Se resources available, in order to reduce adverse environmental effects in systems where Se fertilisation is applied, and/or in organic farming systems where Se fertilisation is not allowed. Considering the similarities between Se and S, and that plants with high $\mathrm{S}$ demand also tend to take up more Se, it seems likely that there will also be beneficial effects from catch crops on Se leaching. The objective of the present work was to test the following hypotheses: 1) catch crops will reduce soil water soluble Se content and thereby leaching risk; 2) incorporation of catch crops will increase the Se availability for the next cash crop by mineralisation; 3) that crucifer catch crops will have a higher Se uptake and concentration, and thereby have a stronger effect on Se leaching risk and Se availability for the succeeding crop than other typical grass or legume catch crops; and 4) S released from crucifer catch crops will reduce Se uptake by the succeeding crop.

\section{Materials and methods}

Field experiments

Field experiments were established to study the effect of different catch crop species on Se uptake of 
vegetables at the Department of Food Science, Aarhus University, Aarslev, Denmark $\left(10^{\circ} 27^{\prime} \mathrm{E}, 55^{\circ} 18^{\prime} \mathrm{N}\right)$ on an Agrudalf soil (Table 1). Experiments were performed three times, in 2007/08, 2008/09 and 2009/10. During the experimental period, rainfall and air temperature were recorded daily at a meteorological station located within the experimental area. Average monthly precipitation and average air temperature during the experimental period are shown in Fig. 1. Mean annual precipitation at the site was $624 \mathrm{~mm}$ and mean annual air temperature was $7.8^{\circ} \mathrm{C}$.

The catch crop species were Italian ryegrass (Lolium multiflorum L.), fodder radish (Raphanus sativus L.) and hairy vetch (Vicia villosa Roth). A control treatment without catch crops was included. The experiments had a randomised complete block design with 4 replicates. The catch crop plots were 2.5 by $10 \mathrm{~m}$. Italian ryegrass and fodder radish were sown at a rate of $20 \mathrm{~kg} \mathrm{ha}^{-1}$ and hairy vetch at a rate of $100 \mathrm{~kg} \mathrm{ha}^{-1}$ on 02,11 and 06 August, respectively over the 3 years. The catch crops were incorporated into the soil by ploughing at the end of March.

In 2007/08 (Experiment I), onions and cabbages were used as the cash crops and were transplanted on 20 April 2008. No fertilisation was applied for catch or cash crops. Experiment I showed that the natural Se concentration was extremely low, therefore the next 2 years only onions were used as the cash crop in order to focus on the effects of Se and S inputs on the system. In 2008/09 (Experiment II), fertilisation was applied only to the cash crop and at two $\mathrm{S}\left(0\right.$ and $\left.65 \mathrm{~kg} \mathrm{ha}^{-1}\right)$ and two Se $\left(0\right.$ and $\left.10 \mathrm{~g} \mathrm{ha}^{-1}\right)$ levels in four combinations. In 2009/10 (Experiment III), two levels of Se fertilisation ( 0 and $10 \mathrm{~g} \mathrm{ha}^{-1}$ ) were applied to both the catch and cash crops. Fertiliser was applied manually; Se was applied as a liquid fertiliser in the form of sodium selenate $\left(\mathrm{Na}_{2} \mathrm{SeO}_{4}\right)$ and $\mathrm{S}$ as a granular fertiliser in the form of Kieserite $\left(\mathrm{MgSO}_{4}\right)$. Each year, the experiments were established in different plots in the same experimental field.

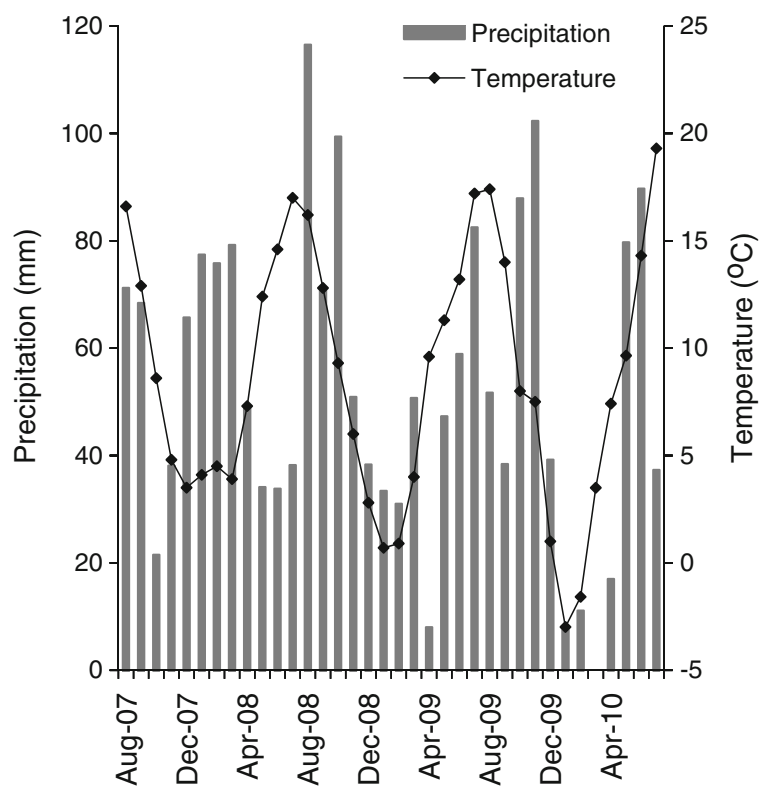

Fig. 1 Monthly precipitation (bars) and average monthly temperature (line) during the experiment

Plant sampling and analysis

For each catch crop plot, plant samples from $1 \mathrm{~m}^{2}$ were collected in mid-November (except in Experiment I) by cutting the plant material at the soil surface. At harvest, cabbages were sampled from 3 $\mathrm{m}^{2}$, and onions from $2,1.2$ and $0.72 \mathrm{~m}^{2}$ respectively for all the 3 years. In Experiment I, cash crops were analysed only for Se, for this analysis plant material was oven-dried plant material. For the cabbage analysis only uniform cabbage heads with smooth leaves were used, and the non-wrapped leaves were removed. Plants with crinkled leaves were excluded from analysis. After harvest, the onions were separated into bulbs and leaves analysis has undertaken only on the bulbs. Yield, dry matter (DM), N, S and Se accumulation were determined both in catch and cash crops. An overview of the experimental protocols is provided in Table 2.
Table 1 Main soil characteristics at the experimental site

Where C: carbon; $\mathrm{N}$ : nitrogen

\begin{tabular}{lllllll}
\hline Depth (m) & Clay (\%) & Silt (\%) & Sand (\%) & $\mathrm{C}(\%)$ & $\mathrm{N}(\%)$ & $\mathrm{pH}_{\mathrm{CaCl}_{2}}$ \\
\hline $0-0.25$ & 15 & 27 & 55 & 1.8 & 0.16 & 7.0 \\
$0.25-0.5$ & 18 & 29 & 52 & 0.8 & 0.07 & 6.4 \\
$0.5-0.75$ & 21 & 28 & 50 & 0.3 & 0.04 & 5.1 \\
$0.75-1.0$ & 21 & 27 & 53 & 0.2 & 0.03 & 5.7 \\
\hline
\end{tabular}


Table 2 Overview of crops and the experimental protocol for each of the three experiments
Where DM: dry matter; Se: selenium; S: sulphur; N: nitrogen.

\begin{tabular}{|c|c|c|c|}
\hline $\begin{array}{l}\text { Treatments } \\
\text { Year }\end{array}$ & $\begin{array}{l}\text { Experiment I } \\
2007 / 08\end{array}$ & $\begin{array}{l}\text { Experiment II } \\
2008 / 09\end{array}$ & $\begin{array}{l}\text { Experiment III } \\
2009 / 10\end{array}$ \\
\hline \multicolumn{4}{|l|}{ Catch crops } \\
\hline Species & $\begin{array}{l}\text { Italian ryegrass } \\
\text { Hairy vetch } \\
\text { Fodder radish }\end{array}$ & $\begin{array}{l}\text { Italian ryegrass } \\
\text { Hairy vetch } \\
\text { Fodder radish }\end{array}$ & $\begin{array}{l}\text { Italian ryegrass, } \\
\text { Hairy vetch, } \\
\text { Fodder radish }\end{array}$ \\
\hline Fertilisation & None & None & $\begin{array}{l}0 \mathrm{~g} \mathrm{Se} \mathrm{ha}{ }^{-1} \\
10 \mathrm{~g} \mathrm{Se} \mathrm{ha}^{-1}\end{array}$ \\
\hline $\begin{array}{l}\text { Analysis } \\
\text { Cash crops }\end{array}$ & $\mathrm{DM}$ & $\mathrm{DM}, \mathrm{Se}, \mathrm{S}, \mathrm{N}$ & $\mathrm{DM}, \mathrm{Se}, \mathrm{S}, \mathrm{N}$ \\
\hline Species & Onions, cabbages & Onions & Onions \\
\hline Fertilisation & None & $\begin{array}{l}\text { None, } \\
0 \mathrm{~kg} \mathrm{~S} \mathrm{ha}{ }^{-1}+10 \mathrm{~g} \mathrm{Se} \mathrm{ha}^{-1} \\
65 \mathrm{~kg} \mathrm{~S} \mathrm{ha}^{-1}+0 \mathrm{~g} \mathrm{Se} \mathrm{ha}^{-1} \\
65 \mathrm{~kg} \mathrm{~S} \mathrm{ha}^{-1}+10 \mathrm{~g} \mathrm{Se} \mathrm{ha}^{-1}\end{array}$ & $\begin{array}{l}0 \mathrm{~g} \mathrm{Se} \mathrm{ha}^{-1} \\
10 \mathrm{~g} \mathrm{Se} \mathrm{ha}^{-1}\end{array}$ \\
\hline Analysis & $\mathrm{DM}, \mathrm{Se}$ & $\mathrm{DM}, \mathrm{Se}, \mathrm{S}, \mathrm{N}$ & $\mathrm{DM}, \mathrm{Se}, \mathrm{S}, \mathrm{N}$ \\
\hline \multicolumn{4}{|l|}{ Soil sampling } \\
\hline Autumn & None & $\mathrm{Se}, \mathrm{S}$ (3 layers to $1.5 \mathrm{~m}$ depth) & $\mathrm{Se}, \mathrm{S}$ (3 layers to $1.5 \mathrm{~m}$ depth) \\
\hline Spring & None & Se, $\mathrm{S}$ (top soil) & Se, $\mathrm{S}$ (top soil) \\
\hline
\end{tabular}

Plant samples were dried at $80^{\circ} \mathrm{C}$ in a forced airdrying oven for $20 \mathrm{~h}$ prior to $\mathrm{N}$ and $\mathrm{S}$ analysis. Total plant $\mathrm{N}$ was determined following dry oxidation by the Dumas method (Elementar Vario EL., Hanau., Germany) and total S by using a NDIR (nondispersive infrared gas analysis) optic to detect the sulphur dioxide formed. Both measurements were carried out in duplicate.

Prior to Se analysis, a subsample of fresh plant material was washed with de-ionised water to remove the attached soil then frozen and freeze dried. Finely ground material $(400 \mathrm{mg}$ ) was microwave-digested in pressurised perfluroalkoxy (PFA) vessels (Anton Paar, 'Multiwave') with $3 \mathrm{~mL}$ of $70 \%$ Fisher 'Trace analysis grade' (TAG) $\mathrm{HNO}_{3}, 3 \mathrm{~mL}$ water and $2 \mathrm{~mL}$ of $30 \% \mathrm{H}_{2} \mathrm{O}_{2}$. Digested samples were diluted to 15 $\mathrm{mL}$ with milli-Q water $(18.2 \mathrm{M} \Omega \mathrm{cm})$ and, immediately prior to analysis, were further diluted 1-in-10 with milli-Q water. Concentrations of Se in plant samples and leachate were determined using an Inductively Coupled Plasma Mass Spectrometer (ICP-MS, Thermo-Fisher Scientific X-Series ${ }^{\mathrm{II}}$ ) employing a 'hexapole collision-reaction cell' (with $\mathrm{H}_{2}$ gas) with kinetic energy discrimination (CCT-KED) to remove polyatomic interferences. The quality of plant Se analysis was tested using the
Certified Reference Material NIST-1573a (Tomato Leaves); Se concentrations were within $10 \%$ of the certified value $\left(0.054 \mathrm{mg} \mathrm{kg}^{-1}\right)$.

Soil sampling and analysis

Soil samples were taken in November in soil layers at $0-0.25 \mathrm{~m}, 0.25-0.75 \mathrm{~m}$ and $0.75-1.5 \mathrm{~m}$ depth and in March, prior to catch crop incorporation from the topsoil $(0-0.25 \mathrm{~m})$. Nine distributed soil samples were taken from each plot with a piston auger (inner diameter $14 \mathrm{~mm}$ ) and bulked to provide a single sample for each depth interval from each plot for soil characterisation. The soil samples were frozen at $-18^{\circ} \mathrm{C}$ within $24 \mathrm{~h}$ after sampling. Total inorganic sulphate was extracted by shaking soil $(40 \mathrm{~g})$ with $400 \mathrm{ml} \mathrm{CaCl} 2(0.0125$ M) for $60 \mathrm{~min}$. Extracts were filtered and sulphate was measured using an inductively coupled plasmaoptical emission spectrometer (ICP-OES). Watersoluble Se was extracted with deionised water at a water-to-soil ratio of 10:1 (W/W); suspensions were shaken for $60 \mathrm{~min}$, and then centrifuged for $20 \mathrm{~min}$ at $10000 \mathrm{rpm}$. The supernatant was filtered to $<0.22$ $\mu \mathrm{m}$, acidified to $2 \% \mathrm{HNO}_{3}$ and stored at $4{ }^{\circ} \mathrm{C}$ prior to Se analysis by ICP-MS. 


\section{Data analysis}

Selenium recovery $\left(\mathrm{Se}_{\mathrm{R}} ; \%\right)$ was calculated from equation 1:

$\mathrm{Se}_{\mathrm{R}}=\frac{\mathrm{Se}_{\mathrm{up}}^{\mathrm{F}}-\mathrm{Se}_{\mathrm{up}}^{\mathrm{o}}}{\mathrm{Se}_{\mathrm{app}}} \times 100$

Where $\mathrm{Se}^{\mathrm{F}}$ up and $\mathrm{Se}_{\text {up }}^{\mathrm{o}}$ are $\mathrm{Se}$ uptake from soil fertilised with Se and from control plots, respectively; $\mathrm{Se}_{\text {app }}$ is the amount of Se applied.

Statistical analysis of the data was performed using the GLM procedure of the SAS statistical package (Version 9.2; SAS Institute Inc, Cary, NC, USA). If the assumption of normality or homogeneity of variance was not verified, log-transformed data were used.

\section{Results}

Soil extractable Se and S content

The effect of catch crops on water-extractable soil Se content during their growth in the autumn and immediately prior to their incorporation into the soil in spring was limited and inconsistent. During the autumn period of Experiment II, the catch crops did not influence water-extractable Se content in the soil or the Se distribution in the soil profiles (Table 3). Although total soil extractable sulphate content was unaffected by the catch crops, the amount of sulphate in the topsoil $(0-0.25 \mathrm{~m})$ decreased after incorporation of Italian ryegrass and fodder radish, but increased after hairy vetch (Table 3 ). In the 0.25 $0.75 \mathrm{~m}$ layer, fodder radish significantly reduced soil extractable sulphate content. Moreover a reduced soil sulphate content was observed in the $0.75-1.5 \mathrm{~m}$ layer after the fodder radish (non-significant). During the spring in Experiment II, soil water-extractable Se content in the topsoil showed a small increase after catch crops (non-significant) (Table 3). A nonsignificant increase in extractable sulphate content in the $0-0.25 \mathrm{~m}$ soil layer was observed after fodder radish, while Italian ryegrass appeared to reduce soil sulphate (non-significant) (Table 3).

In Experiment III, catch crops increased both the soil water-extractable Se content and affected its distribution in the soil during autumn (Table 4). Catch crops influenced soluble Se content mainly in the $0.25-0.75 \mathrm{~m}$ soil layer where soil Se content was higher under Italian ryegrass and fodder radish than in the bare soil (Table 4). Total water-extractable soil Se content was affected by the catch crops only when Se fertilisation had been applied. Italian ryegrass and fodder radish caused a significant increase in soil water-extractable Se content.

In Experiment III, the catch crops differed not only in their effect on the amount of soil extractable sulphate, but also in their effect on its vertical distribution (Table 4). Fodder radish reduced total extractable soil sulphate by 15 to $23 \mathrm{~kg} \mathrm{~S} \mathrm{ha}^{-1}$ as compared to bare soil. In autumn, the extractable $\mathrm{S}$ content in the bare soil was high at $0.25-1.5 \mathrm{~m}$ depth. As in Experiment II, topsoil extractable sulphate content was higher under hairy vetch compared to bare soil, fodder radish and Italian ryegrass. All catch crops reduced the extractable $\mathrm{S}$ content in the $0.25-$

Table 3 Soil Se $\left(\mathrm{g} \mathrm{ha}^{-1}\right)$ and $\mathrm{S}\left(\mathrm{kg} \mathrm{ha}^{-1}\right)$ content and distribution during autumn and spring in Experiment II under different catch crops

\begin{tabular}{|c|c|c|c|c|c|c|c|c|c|c|}
\hline \multirow{3}{*}{$\begin{array}{l}\text { Catch } \\
\text { crops }\end{array}$} & \multicolumn{5}{|c|}{ Soil soluble Se $\left(\mathrm{g} \mathrm{ha}^{-1}\right)$} & \multicolumn{5}{|c|}{ Soil inorganic $\mathrm{S}\left(\mathrm{kg} \mathrm{ha}^{-1}\right)$} \\
\hline & \multicolumn{4}{|c|}{ Autumn 2008} & \multirow{2}{*}{$\begin{array}{l}\text { Spring } \\
2009 \\
0-0.25 \mathrm{~m}\end{array}$} & \multicolumn{4}{|c|}{ Autumn 2008} & \multirow{2}{*}{$\begin{array}{l}\text { Spring } \\
2009 \\
0-0.25 \mathrm{~m}\end{array}$} \\
\hline & $0-0.25 \mathrm{~m}$ & $0.25-0.75 \mathrm{~m}$ & $0.75-1.5 \mathrm{~m}$ & Total & & $0-0.25 \mathrm{~m}$ & $0.25-0.75 \mathrm{~m}$ & $0.75-1.5 \mathrm{~m}$ & Total & \\
\hline $\mathrm{C}$ & $28 \pm 1^{\mathrm{a}}$ & $40 \pm 3^{\mathrm{a}}$ & $25 \pm 6^{\mathrm{a}}$ & $93 \pm 8^{\mathrm{a}}$ & $27 \pm 4^{\mathrm{a}}$ & $10 \pm 1^{\mathrm{ab}}$ & $21 \pm 4^{\mathrm{a}}$ & $20 \pm 4^{\mathrm{a}}$ & $49 \pm 5^{\mathrm{a}}$ & $28 \pm 19^{a}$ \\
\hline IR & $29 \pm 2^{\mathrm{a}}$ & $44 \pm 5^{\mathrm{a}}$ & $32 \pm 10^{\mathrm{a}}$ & $105 \pm 16^{\mathrm{a}}$ & $31 \pm 2^{\mathrm{a}}$ & $7 \pm 1^{\mathrm{c}}$ & $17 \pm 4^{\mathrm{a}}$ & $26 \pm 2^{\mathrm{a}}$ & $50 \pm 3^{\mathrm{a}}$ & $23 \pm 14^{\mathrm{a}}$ \\
\hline FR & $28 \pm 2^{\mathrm{a}}$ & $39 \pm 6^{\mathrm{a}}$ & $30 \pm 10^{\mathrm{a}}$ & $97 \pm 15^{\mathrm{a}}$ & $28 \pm 4^{\mathrm{a}}$ & $9 \pm 2^{\mathrm{c}}$ & $10 \pm 7^{\mathrm{b}}$ & $15 \pm 11^{\mathrm{a}}$ & $34 \pm 17^{\mathrm{a}}$ & $33 \pm 21^{\mathrm{a}}$ \\
\hline $\mathrm{HV}$ & $29 \pm 2^{\mathrm{a}}$ & $37 \pm 4^{\mathrm{a}}$ & $29 \pm 6^{\mathrm{a}}$ & $94 \pm 10^{\mathrm{a}}$ & $27 \pm 2^{\mathrm{a}}$ & $11 \pm 1^{\mathrm{a}}$ & $16 \pm 3^{\mathrm{a}}$ & $26 \pm 4^{\mathrm{a}}$ & $53 \pm 6^{\mathrm{a}}$ & $26 \pm 22^{\mathrm{a}}$ \\
\hline
\end{tabular}

Where Se: selenium; S: sulphur; C: bare soil; IR: Italian ryegrass; FR: fodder radish; HV: hairy vetch

Means followed by the same letter are not significantly different $(n=4)$ 
Table 4 Soil Se $\left(\mathrm{g} \mathrm{ha}^{-1}\right)$ and $\mathrm{S}\left(\mathrm{kg} \mathrm{ha}^{-1}\right)$ content and distribution in the autumn and spring in Experiment III under different catch crops

\begin{tabular}{|c|c|c|c|c|c|c|c|c|c|c|c|}
\hline \multirow[t]{3}{*}{ Fertilisation } & \multirow{3}{*}{$\begin{array}{l}\text { Catch } \\
\text { crops }\end{array}$} & \multicolumn{5}{|c|}{ Soil soluble Se $\left(\mathrm{g} \mathrm{ha}^{-1}\right)$} & \multicolumn{5}{|c|}{ Soil inorganic $\mathrm{S}\left(\mathrm{kg} \mathrm{ha}^{-1}\right)$} \\
\hline & & \multicolumn{4}{|c|}{ Autumn 2009} & \multirow{2}{*}{$\begin{array}{l}\text { Spring } \\
2010 \\
0-0.25 \mathrm{~m}\end{array}$} & \multicolumn{4}{|c|}{ Autumn 2009} & \multirow{2}{*}{$\begin{array}{l}\text { Spring } \\
2010 \\
0-0.25 \mathrm{~m}\end{array}$} \\
\hline & & $0-0.25 \mathrm{~m}$ & $\begin{array}{l}0.25- \\
0.75 \mathrm{~m}\end{array}$ & $0.75-1.5 \mathrm{~m}$ & Total & & $0-0.25 \mathrm{~m}$ & $\begin{array}{l}0.25- \\
0.75 \mathrm{~m}\end{array}$ & $0.75-1.5 \mathrm{~m}$ & Total & \\
\hline \multirow[t]{5}{*}{$\mathrm{Se}_{0}$} & $\mathrm{C}$ & $29 \pm 2^{\mathrm{a}}$ & $40 \pm 4^{b}$ & $38 \pm 7^{\mathrm{a}}$ & $106 \pm 5^{\mathrm{a}}$ & $27 \pm 1^{\mathrm{a}}$ & $8 \pm 1^{\mathrm{b}}$ & $16 \pm 2^{\mathrm{a}}$ & $16 \pm 2^{\mathrm{ab}}$ & $40 \pm 1^{\mathrm{a}}$ & $9 \pm 1^{d}$ \\
\hline & IR & $28 \pm 0^{\mathrm{a}}$ & $45 \pm 5^{\mathrm{a}}$ & $36 \pm 7^{\mathrm{a}}$ & $108 \pm 11^{\mathrm{a}}$ & $26 \pm 2^{\mathrm{a}}$ & $6 \pm 1^{\mathrm{b}}$ & $11 \pm 3^{\mathrm{ab}}$ & $19 \pm 4^{\mathrm{a}}$ & $36 \pm 4^{\mathrm{a}}$ & $11 \pm 1^{\mathrm{c}}$ \\
\hline & FR & $28 \pm 2^{\mathrm{a}}$ & $44 \pm 4^{\mathrm{a}}$ & $38 \pm 6^{\mathrm{a}}$ & $109 \pm 9^{\mathrm{a}}$ & $26 \pm 1^{\mathrm{a}}$ & $7 \pm 4^{\mathrm{b}}$ & $4 \pm 0^{\mathrm{c}}$ & $6 \pm 0^{\mathrm{c}}$ & $17 \pm 4^{\mathrm{b}}$ & $22 \pm 2^{\mathrm{a}}$ \\
\hline & HV & $28 \pm 1^{\mathrm{a}}$ & $43 \pm 1^{\mathrm{ab}}$ & $32 \pm 4^{\mathrm{a}}$ & $102 \pm 3^{\mathrm{a}}$ & $26 \pm 0^{\mathrm{a}}$ & $12 \pm 3^{\mathrm{a}}$ & $8 \pm 5^{\mathrm{bc}}$ & $13 \pm 10^{\mathrm{b}}$ & $33 \pm 17^{\mathrm{a}}$ & $14 \pm 3^{\mathrm{b}}$ \\
\hline & Average & $28 \pm 1^{\mathrm{B}}$ & $43 \pm 4^{\mathrm{A}}$ & $36 \pm 6^{\mathrm{A}}$ & $107 \pm 7^{\mathrm{A}}$ & $26 \pm 1^{\mathrm{A}}$ & $8 \pm 3^{\mathrm{A}}$ & $10 \pm 5^{\mathrm{A}}$ & $14 \pm 7^{\mathrm{A}}$ & $30 \pm 10^{\mathrm{A}}$ & $14 \pm 6^{\mathrm{A}}$ \\
\hline \multirow[t]{5}{*}{$\mathrm{Se}_{10}$} & $\mathrm{C}$ & $28 \pm 2^{\mathrm{a}}$ & $40 \pm 3^{\mathrm{c}}$ & $36 \pm 3^{\mathrm{a}}$ & $104 \pm 5^{b}$ & $27 \pm 0^{\mathrm{a}}$ & $7 \pm 1^{\mathrm{b}}$ & $15 \pm 2^{\mathrm{a}}$ & $10 \pm 5^{\mathrm{a}}$ & $32 \pm 5^{\mathrm{a}}$ & $10 \pm 2^{\mathrm{c}}$ \\
\hline & IR & $30 \pm 0^{\mathrm{a}}$ & $45 \pm 2^{\mathrm{ab}}$ & $45 \pm 5^{\mathrm{a}}$ & $119 \pm 4^{\mathrm{a}}$ & $27 \pm 1^{\mathrm{ab}}$ & $5 \pm 1^{\mathrm{c}}$ & $10 \pm 4^{\mathrm{b}}$ & $15 \pm 7^{\mathrm{a}}$ & $29 \pm 11^{\mathrm{a}}$ & $10 \pm 1^{\mathrm{c}}$ \\
\hline & FR & $29 \pm 1^{\mathrm{a}}$ & $47 \pm 3^{\mathrm{a}}$ & $39 \pm 7^{\mathrm{a}}$ & $115 \pm 9^{\mathrm{a}}$ & $26 \pm 1^{b c}$ & $5 \pm 1^{\mathrm{c}}$ & $4 \pm 0^{\mathrm{c}}$ & $9 \pm 5^{\mathrm{a}}$ & $17 \pm 5^{\mathrm{b}}$ & $21 \pm 5^{\mathrm{a}}$ \\
\hline & $\mathrm{HV}$ & $29 \pm 2^{\mathrm{a}}$ & $42 \pm 3^{b c}$ & $39 \pm 4^{\mathrm{a}}$ & $110 \pm 7^{\mathrm{ab}}$ & $25 \pm 1^{\mathrm{c}}$ & $12 \pm 4^{\mathrm{a}}$ & $8 \pm 4^{\mathrm{bc}}$ & $9 \pm 5^{\mathrm{a}}$ & $29 \pm 10^{\mathrm{a}}$ & $15 \pm 2^{b}$ \\
\hline & Average & $29 \pm 1^{\mathrm{A}}$ & $43 \pm 4^{\mathrm{A}}$ & $40 \pm 6^{\mathrm{A}}$ & $112 \pm 8^{\mathrm{A}}$ & $26 \pm 1^{\mathrm{A}}$ & $7 \pm 4^{\mathrm{A}}$ & $9 \pm 5^{\mathrm{A}}$ & $11 \pm 6^{\mathrm{A}}$ & $26 \pm 10^{\mathrm{A}}$ & $14 \pm 5^{\mathrm{A}}$ \\
\hline
\end{tabular}

Where Se: selenium; S: sulphur; $\mathrm{Se}_{0}: 0 \mathrm{~g} \mathrm{Se} \mathrm{ha}^{-1} ; \mathrm{Se}_{10}: 10 \mathrm{~g} \mathrm{Se} \mathrm{ha}^{-1}$; C: bare soil; IR: Italian ryegrass; FR: fodder radish; HV: hairy vetch

Mean values of the three catch crops and bare soil treatments in the same fertilisation treatment by different letters (a, b, c) are significantly different. Mean values for fertilisation treatment followed by different capital letters (A, B, C) are significantly different $(n=4)$

$0.75 \mathrm{~m}$ soil layer, especially fodder radish. In the $0.25-0.75 \mathrm{~m}$ soil layer, extractable $\mathrm{S}$ content under fodder radish was only $26 \%$ of that in the bare soil. Fodder radish grown without $\mathrm{Se}$ fertilisation decreased extractable $\mathrm{S}$ content also in the $0.75-1.5 \mathrm{~m}$ soil layer. Soil extractable sulphate content was unaffected by Se fertilisation in autumn in Experiment III (Table 4).

Selenium fertilisation did not influence water soluble Se and extractable S content in the topsoil in spring in Experiment II (Table 4). Catch crops affected water soluble Se content in the topsoil only when grown with Se fertilisation (Table 4). Fodder radish and hairy vetch reduced water soluble soil Se content compared to bare soil. Extractable soil S content in the topsoil was increased under fodder radish and hairy vetch (Table 4 ).

\section{Catch crops}

Plant production in catch crops, from the midAugust to mid-November, was on average 5.4, 3.6, 2.1 Mg dry matter per ha for fodder radish, Italian ryegrass and hairy vetch, respectively (Table 5). Fodder radish produced higher yields in
Experiment III than in Experiment I (data not shown) and Experiment II, whereas the yields of Italian ryegrass and hairy vetch were constant. Selenium fertilisation did not affect catch crop yields in Experiment III.

Significant differences in Se concentrations and uptake in catch crops were found both in Experiment II and III (Table 5). Selenium concentrations were 2 to 10 times higher in fodder radish grown with and without Se fertiliser compared to Italian ryegrass and hairy vetch; Se uptake was 4 to 24 times higher by fodder radish than by the other catch crops. Application of $10 \mathrm{~g} \mathrm{Se} \mathrm{ha}{ }^{-1}$ significantly increased Se concentrations and uptake by catch crops. The Se recovery by fodder radish, Italian ryegrass and hairy vetch was $17 \%, 7 \%$ and $6 \%$, respectively. Sulphur and $\mathrm{N}$ uptake were higher by fodder radish both in Experiments II and III (Table 5). Selenium fertilisation did not influence $\mathrm{S}$ and $\mathrm{N}$ uptake by catch crops in Experiment III.

\section{Cash crops}

In Experiment I, none of the catch crops affected onion yield, but cabbage yield was higher follow- 
Table 5 Yield $\left(\mathrm{Mg} \mathrm{DM} \mathrm{ha}^{-1}\right)$, Se content $\left(\mu \mathrm{g} \mathrm{kg}^{-1}\right)$, Se uptake $\left(\mathrm{mg} \mathrm{ha}^{-1}\right)$, S- and $\mathrm{N}$-uptake $\left(\mathrm{kg} \mathrm{ha}^{-1}\right)$ in catch crops in Experiments II and III

\begin{tabular}{|c|c|c|c|c|c|c|}
\hline Fertilisation & Catch crops & $\begin{array}{l}\text { Yield } \\
\left(\mathrm{Mg} \mathrm{DM} \mathrm{ha}^{-1}\right)\end{array}$ & Se-content $\left(\mu \mathrm{g} \mathrm{kg}^{-1}\right)$ & Se-uptake $\left(\mathrm{mg} \mathrm{ha}^{-1}\right)$ & N-uptake $\left(\mathrm{kg} \mathrm{ha}^{-1}\right)$ & S-uptake $\left(\mathrm{kg} \mathrm{ha}^{-1}\right)$ \\
\hline \multicolumn{7}{|l|}{2008} \\
\hline \multirow[t]{4}{*}{$\mathrm{Se}_{0}$} & IR & $3.2 \pm 0.4^{\mathrm{b}}$ & $41 \pm 5^{\mathrm{c}}$ & $130 \pm 26^{\mathrm{b}}$ & $83 \pm 9^{b}$ & $6 \pm 1^{b}$ \\
\hline & FR & $4.3 \pm 0.7^{\mathrm{a}}$ & $212 \pm 86^{\mathrm{a}}$ & $997 \pm 315^{\mathrm{a}}$ & $147 \pm 34^{\mathrm{a}}$ & $26 \pm 5^{\mathrm{a}}$ \\
\hline & $\mathrm{HV}$ & $2.0 \pm 0.4^{\mathrm{c}}$ & $85 \pm 17^{\mathrm{b}}$ & $177 \pm 63^{\mathrm{b}}$ & $74 \pm 11^{\mathrm{b}}$ & $4 \pm 1^{\mathrm{c}}$ \\
\hline & Average & $3.2 \pm 1.1$ & $93 \pm 73$ & $322 \pm 374$ & $101 \pm 39$ & $12 \pm 11$ \\
\hline \multicolumn{7}{|l|}{2009} \\
\hline \multirow[t]{4}{*}{$\mathrm{Se}_{0}$} & IR & $3.8 \pm 0.2^{\mathrm{b}}$ & $30 \pm 1^{\mathrm{b}}$ & $114 \pm 12^{\mathrm{b}}$ & $132 \pm 6^{\mathrm{b}}$ & $8 \pm 1^{\mathrm{b}}$ \\
\hline & FR & $5.6 \pm 0.7^{\mathrm{a}}$ & $288 \pm 182^{\mathrm{a}}$ & $1571 \pm 1125^{\mathrm{a}}$ & $202 \pm 8^{\mathrm{a}}$ & $28 \pm 3^{\mathrm{a}}$ \\
\hline & $\mathrm{HV}$ & $2.1 \pm 0.5^{\mathrm{c}}$ & $31 \pm 3^{\mathrm{b}}$ & $65 \pm 13^{\mathrm{b}}$ & $108 \pm 26^{\mathrm{b}}$ & $5 \pm 2^{\mathrm{c}}$ \\
\hline & Average & $3.8 \pm 1.6^{\mathrm{A}}$ & $101 \pm 145^{\mathrm{B}}$ & $494 \pm 856^{\mathrm{B}}$ & $148 \pm 44^{\mathrm{A}}$ & $13 \pm 11^{\mathrm{A}}$ \\
\hline \multirow[t]{4}{*}{$\mathrm{Se}_{10}$} & IR & $3.8 \pm 0.6^{\mathrm{b}}$ & $202 \pm 13^{\mathrm{c}}$ & $773 \pm 138^{\mathrm{b}}$ & $136 \pm 18^{b}$ & $8 \pm 1^{\mathrm{b}}$ \\
\hline & FR & $6.2 \pm 1.0^{\mathrm{a}}$ & $514 \pm 87^{\mathrm{a}}$ & $3263 \pm 1070^{\mathrm{a}}$ & $223 \pm 35^{\mathrm{a}}$ & $29 \pm 7^{\mathrm{a}}$ \\
\hline & $\mathrm{HV}$ & $2.2 \pm 0.7^{\mathrm{c}}$ & $316 \pm 71^{\mathrm{b}}$ & $663 \pm 191^{\mathrm{b}}$ & $112 \pm 36^{\mathrm{b}}$ & $4 \pm 2^{\mathrm{c}}$ \\
\hline & Average & $4.1 \pm 1.9^{\mathrm{A}}$ & $344 \pm 147^{\mathrm{A}}$ & $1566 \pm 1378^{\mathrm{A}}$ & $157 \pm 57^{\mathrm{A}}$ & $14 \pm 12^{\mathrm{A}}$ \\
\hline
\end{tabular}

Where Se: selenium; S: sulphur; $\mathrm{Se}_{0}: 0 \mathrm{~g} \mathrm{Se} \mathrm{ha}^{-1} ; \mathrm{Se}_{10}: 10 \mathrm{~g} \mathrm{Se} \mathrm{ha}{ }^{-1}$; C: bare soil; IR: Italian ryegrass; FR: fodder radish; HV: hairy vetch Mean values of the three catch crops and bare soil treatments in the same fertilisation treatment by different letters (a, b, c) are significantly different. Mean values for fertilisation treatment followed by different capital letters (A, B, C) are significantly different $(n=4)$

ing both fodder radish and hairy vetch (Table 6). Selenium concentrations in onions were reduced following incorporation of Italian ryegrass and hairy vetch catch crops, whereas in cabbages the Se concentrations remained unaffected by the catch crops (Table 6). Cabbages contained 4 to 12 times higher Se concentrations and had 2 to 6 times higher total Se uptake than onions. A nonsignificant decrease in Se uptake by onions following catch crops was observed. Increased cabbage yields following fodder radish and hairy vetch resulted in a higher Se uptake by cabbages grown after these catch crops.

In Experiment II, only incorporation of hairy vetch increased the yield of onions in the $\mathrm{Se}_{10} \mathrm{~S}_{0}$ treatment (Table 7). In Experiment III there was an increase in onions yield following fodder radish and hairy vetch where no Se fertiliser was given $\left(\mathrm{Se}_{0} \mathrm{Se}_{0}\right)$ and where Se fertiliser was added both in the autumn and in the spring $\left(\mathrm{Se}_{10} \mathrm{Se}_{10}\right.$, Table 8). Overall there was no significant effect of the fertilisation treatments on the onion yields.

Table 6 Yield $\left(\mathrm{Mg} \mathrm{DM} \mathrm{ha}^{-1}\right)$, Se content $\left(\mu \mathrm{g} \mathrm{kg}^{-1}\right)$, Se uptake $\left(\mathrm{mg} \mathrm{ha}^{-1}\right)$ in onions and cabbages following catch crops in Experiment I

\begin{tabular}{|c|c|c|c|c|c|c|}
\hline \multirow[t]{2}{*}{ Catch crops } & \multicolumn{3}{|l|}{ Onions } & \multicolumn{3}{|l|}{ Cabbage } \\
\hline & $\begin{array}{l}\text { Yield } \\
\left(\mathrm{Mg} \mathrm{DM} \mathrm{ha}{ }^{-1}\right)\end{array}$ & $\begin{array}{l}\text { Se content } \\
\left(\mu \mathrm{g} \mathrm{kg}^{-1}\right)\end{array}$ & $\begin{array}{l}\text { Se-uptake } \\
\left(\mathrm{mg} \mathrm{ha}^{-1}\right)\end{array}$ & $\begin{array}{l}\text { Yield } \\
\left(\mathrm{Mg} \mathrm{DM} \mathrm{ha}^{-1}\right)\end{array}$ & $\begin{array}{l}\text { Se content } \\
\left(\mu \mathrm{g} \mathrm{kg}^{-1}\right)\end{array}$ & $\begin{array}{l}\text { Se-uptake } \\
\left(\mathrm{mg} \mathrm{ha}^{-1}\right)\end{array}$ \\
\hline $\mathrm{C}$ & $8.9 \pm 0.6^{\mathrm{a}}$ & $6 \pm 0.3^{\mathrm{a}}$ & $49 \pm 1.4^{\mathrm{a}}$ & $4.1 \pm 0.5^{\mathrm{b}}$ & $24 \pm 6.2^{\mathrm{a}}$ & $97 \pm 23.1^{\mathrm{bc}}$ \\
\hline IR & $9.1 \pm 0.6^{\mathrm{a}}$ & $3 \pm 0.3^{\mathrm{c}}$ & $24 \pm 2.5^{\mathrm{bc}}$ & $3.4 \pm 0.4^{\mathrm{c}}$ & $22 \pm 6.0^{\mathrm{a}}$ & $71 \pm 15.4^{\mathrm{c}}$ \\
\hline FR & $9.8 \pm 0.7^{\mathrm{a}}$ & $2 \pm 0.5^{b c}$ & $21 \pm 5.3^{\mathrm{c}}$ & $4.9 \pm 0.5^{\mathrm{a}}$ & $23 \pm 5.1^{\mathrm{a}}$ & $117 \pm 36.3^{\mathrm{ab}}$ \\
\hline $\mathrm{HV}$ & $9.4 \pm 0.7^{\mathrm{a}}$ & $4 \pm 2.6^{\mathrm{ab}}$ & $41 \pm 26.6^{\mathrm{bc}}$ & $5.5 \pm 0.2^{\mathrm{a}}$ & $31 \pm 11.5^{\mathrm{a}}$ & $170 \pm 70.2^{\mathrm{a}}$ \\
\hline
\end{tabular}

Where Se: selenium; S: sulphur; C: bare soil; IR: Italian ryegrass; FR: fodder radish; HV: hairy vetch.

Means followed by the same letter are not significantly different $(n=4)$ 
Table 7 Yield $\left(\mathrm{Mg} \mathrm{DM} \mathrm{ha}{ }^{-1}\right)$, Se content $\left(\mu \mathrm{g} \mathrm{kg}^{-1}\right)$, Se-uptake $\left(\mathrm{mg} \mathrm{ha}^{-1}\right)$, S- and $\mathrm{N}$-uptake $\left(\mathrm{kg} \mathrm{ha}^{-1}\right)$ in onions following catch crops in Experiment II

\begin{tabular}{|c|c|c|c|c|c|c|}
\hline Fertilisation & Catch crops & $\begin{array}{l}\text { Yield } \\
\left(\mathrm{Mg} \mathrm{DM} \mathrm{ha}^{-1}\right)\end{array}$ & $\begin{array}{l}\text { Se-content } \\
\left(\mu \mathrm{g} \mathrm{kg}^{-1}\right)\end{array}$ & $\begin{array}{l}\text { Se-uptake } \\
\left(\mathrm{mg} \mathrm{ha}^{-1}\right)\end{array}$ & $\begin{array}{l}\text { N-uptake } \\
\left(\mathrm{kg} \mathrm{ha}^{-1}\right)\end{array}$ & $\begin{array}{l}\text { S-uptake } \\
\left(\mathrm{kg} \mathrm{ha}^{-1}\right)\end{array}$ \\
\hline \multirow[t]{5}{*}{$\mathrm{Se}_{0} \mathrm{~S}_{0}$} & $\mathrm{C}$ & $4.1 \pm 0.3^{\mathrm{a}}$ & $10 \pm 4.8^{\mathrm{a}}$ & $39 \pm 16.0^{\mathrm{a}}$ & $32 \pm 5.1^{\mathrm{b}}$ & $5 \pm 2.0^{\mathrm{c}}$ \\
\hline & IR & $4.6 \pm 0.8^{\mathrm{a}}$ & $7 \pm 3.8^{\mathrm{a}}$ & $31 \pm 19.1^{\mathrm{a}}$ & $47 \pm 10.6^{\mathrm{a}}$ & $4 \pm 0.7^{\mathrm{c}}$ \\
\hline & FR & $4.5 \pm 0.5^{\mathrm{a}}$ & $8 \pm 9.0^{\mathrm{a}}$ & $31 \pm 35.7^{\mathrm{a}}$ & $50 \pm 6.9^{\mathrm{a}}$ & $9 \pm 1.3^{\mathrm{a}}$ \\
\hline & $\mathrm{HV}$ & $4.6 \pm 0.8^{\mathrm{a}}$ & $2 \pm 2.0^{\mathrm{a}}$ & $10 \pm 9.1^{\mathrm{a}}$ & $53 \pm 9.1^{\mathrm{a}}$ & $7 \pm 0.7^{\mathrm{b}}$ \\
\hline & Average & $4.4 \pm 0.6^{\mathrm{A}}$ & $7 \pm 5.8^{\mathrm{C}}$ & $29 \pm 22.9^{C}$ & $46 \pm 11.1^{\mathrm{A}}$ & $6 \pm 2.3^{\mathrm{B}}$ \\
\hline \multirow[t]{5}{*}{$\mathrm{Se}_{0} \mathrm{~S}_{65}$} & $\mathrm{C}$ & $3.8 \pm 0.2^{\mathrm{a}}$ & $9 \pm 2.2^{\mathrm{a}}$ & $35 \pm 8.9^{\mathrm{a}}$ & $31 \pm 3.7^{\mathrm{c}}$ & $8 \pm 1.9^{\mathrm{b}}$ \\
\hline & IR & $4.2 \pm 0.7^{\mathrm{a}}$ & $5 \pm 5.7^{\mathrm{a}}$ & $23 \pm 22.2^{\mathrm{a}}$ & $44 \pm 6.0^{\mathrm{b}}$ & $10 \pm 1.5^{\mathrm{b}}$ \\
\hline & FR & $5.1 \pm 0.6^{\mathrm{a}}$ & $7 \pm 6.0^{\mathrm{a}}$ & $33 \pm 26.6^{\mathrm{a}}$ & $57 \pm 8.9^{\mathrm{a}}$ & $15 \pm 2.3^{\mathrm{a}}$ \\
\hline & $\mathrm{HV}$ & $4.8 \pm 0.4^{\mathrm{a}}$ & $6 \pm 4.3^{\mathrm{a}}$ & $27 \pm 19.4^{\mathrm{a}}$ & $55 \pm 4.6^{\mathrm{a}}$ & $13 \pm 1.7^{\mathrm{a}}$ \\
\hline & Average & $4.5 \pm 0.7^{\mathrm{A}}$ & $7 \pm 4.5^{\mathrm{C}}$ & $30 \pm 18.9^{\mathrm{C}}$ & $47 \pm 12.3^{\mathrm{A}}$ & $11 \pm 3.4^{\mathrm{A}}$ \\
\hline \multirow[t]{5}{*}{$\mathrm{Se}_{10} \mathrm{~S}_{0}$} & $\mathrm{C}$ & $4.1 \pm 0.2^{\mathrm{b}}$ & $61 \pm 15.0^{\mathrm{a}}$ & $250 \pm 64.0^{\mathrm{a}}$ & $30 \pm 3.5^{\mathrm{d}}$ & $5 \pm 1.5^{\mathrm{bc}}$ \\
\hline & IR & $4.0 \pm 0.3^{\mathrm{b}}$ & $72 \pm 25.1^{\mathrm{a}}$ & $281 \pm 74.9^{\mathrm{a}}$ & $40 \pm 1.4^{\mathrm{c}}$ & $4 \pm 0.9^{\mathrm{c}}$ \\
\hline & FR & $4.6 \pm 0.6^{\mathrm{ab}}$ & $70 \pm 25.8^{\mathrm{a}}$ & $321 \pm 112.4^{\mathrm{a}}$ & $52 \pm 7.7^{\mathrm{a}}$ & $10 \pm 2.3^{\mathrm{a}}$ \\
\hline & $\mathrm{HV}$ & $5.3 \pm 0.6^{\mathrm{a}}$ & $87 \pm 22.7^{\mathrm{a}}$ & $456 \pm 112.4^{\mathrm{a}}$ & $61 \pm 8.0^{\mathrm{b}}$ & $7 \pm 2.3^{\mathrm{ab}}$ \\
\hline & Average & $4.5 \pm 0.7^{\mathrm{A}}$ & $72 \pm 22.4^{\mathrm{A}}$ & $327 \pm 116.6^{\mathrm{A}}$ & $46 \pm 13.1^{\mathrm{A}}$ & $7 \pm 3.2^{\mathrm{B}}$ \\
\hline \multirow[t]{5}{*}{$\mathrm{Se}_{10} \mathrm{~S}_{65}$} & $\mathrm{C}$ & $4.0 \pm 0.3^{\mathrm{a}}$ & $36 \pm 14.0^{\mathrm{a}}$ & $143 \pm 44.5^{\mathrm{a}}$ & $31 \pm 2.5^{\mathrm{c}}$ & $8 \pm 1.7^{\mathrm{c}}$ \\
\hline & IR & $4.1 \pm 1.0^{\mathrm{a}}$ & $40 \pm 13.2^{\mathrm{a}}$ & $157 \pm 48.5^{\mathrm{a}}$ & $42 \pm 10.7^{\mathrm{b}}$ & $10 \pm 3.1^{\mathrm{bc}}$ \\
\hline & FR & $4.5 \pm 0.1^{\mathrm{a}}$ & $48 \pm 34.2^{\mathrm{a}}$ & $214 \pm 153.1^{\mathrm{a}}$ & $52 \pm 1.2^{\mathrm{a}}$ & $10 \pm 1.7^{\mathrm{b}}$ \\
\hline & HV & $5.0 \pm 0.8^{\mathrm{a}}$ & $40 \pm 3.5^{\mathrm{a}}$ & $194 \pm 16.6^{\mathrm{a}}$ & $57 \pm 5.4^{\mathrm{a}}$ & $13 \pm 3.0^{\mathrm{a}}$ \\
\hline & Average & $4.4 \pm 0.7^{\mathrm{A}}$ & $41 \pm 18.1^{\mathrm{B}}$ & $177 \pm 80.4^{\mathrm{B}}$ & $45 \pm 11.8^{\mathrm{A}}$ & $10 \pm 2.9^{\mathrm{A}}$ \\
\hline
\end{tabular}

Where Se: selenium; S: sulphur; $\mathrm{Se}_{0}: 0 \mathrm{~g} \mathrm{Se} \mathrm{ha}^{-1} ; \mathrm{Se}_{10}: 10 \mathrm{~g} \mathrm{Se} \mathrm{ha}^{-1} ; \mathrm{S}_{0}: 0 \mathrm{~kg} \mathrm{~S}^{-1}$; $\mathrm{S}_{65}: 65 \mathrm{~kg} \mathrm{~S}^{-1}$; C: bare soil; IR: Italian ryegrass; FR: fodder radish; HV: hairy vetch

Mean values of the three catch crops and bare soil treatments in the same fertilisation treatment by different letters (a, b, c) are significantly different. Mean values for fertilisation treatment followed by different capital letters (A, B, C) are significantly different $(n=4)$

Selenium concentration in onions was unaffected by catch crops both in Experiments II and III (Tables 7 and 8). As in Experiment I, catch crops reduced Se uptake by onions (non-significant) grown without Se fertiliser in Experiment II (Tables 6 and 7). In contrast, the effect of catch crops on Se uptake by onions was not consistent in Experiment III (Table 8). In Experiments II and III, application of Se to onions at time of transplanting significantly increased plant Se concentrations. However, the average recovery of $\mathrm{Se}$ in onions was low, 1$4 \%$ and $-0.3-0.5 \%$ in Experiment II and III, respectively. In Experiment III, Se fertilisation at the establishment of catch crops in August was found to increase Se concentration and uptake in onions (non-significant), but less effectively than when Se fertiliser was directly applied to the onions. Sulphur fertilisation at transplanting in
Experiment II decreased Se concentrations in onions by up to $54 \%$, when $\mathrm{S}$ was applied with $\mathrm{Se}$, the average Se fertiliser recovery was reduced by up to $75 \%$. The effect of Se fertilisation treatments on Se uptake was similar to the effect on Se concentrations, although a Se fertilisation $\times$ catch crop interaction was observed.

Catch crops influenced $\mathrm{S}$ and $\mathrm{N}$ uptake by onions in Experiments II and III (Tables 7 and 8). Onions grown after catch crops in all treatments took up more $\mathrm{N}$ than those grown after bare soil. Fodder radish and hairy vetch increased $\mathrm{S}$ uptake by onions independently of the fertilisation treatment. In Experiment II, S fertilisation of onions at transplanting increased S uptake, but it did not influence $\mathrm{N}$ uptake (Table 7). Selenium fertilisation did not affect $\mathrm{N}$ or $\mathrm{S}$ uptake by onions in either Experiments II or III (Tables 7 and 8). 
Table 8 Yield $\left(\mathrm{Mg} \mathrm{DM} \mathrm{ha}^{-1}\right)$, Se content $\left(\mu \mathrm{g} \mathrm{kg}^{-1}\right)$, Se-uptake $\left(\mathrm{mg} \mathrm{ha}^{-1}\right)$, S- and $\mathrm{N}$-uptake $\left(\mathrm{kg} \mathrm{ha}^{-1}\right)$ in onions following catch crops in Experiment III

\begin{tabular}{|c|c|c|c|c|c|c|}
\hline Fertilisation & $\begin{array}{l}\text { Catch } \\
\text { crops }\end{array}$ & $\begin{array}{l}\text { Yield } \\
\left(\mathrm{Mg} \mathrm{DM} \mathrm{ha}^{-1}\right)\end{array}$ & $\begin{array}{l}\text { Se-content } \\
\left(\mu \mathrm{g} \mathrm{kg}^{-1}\right)\end{array}$ & $\begin{array}{l}\text { Se-uptake } \\
\left(\mathrm{mg} \mathrm{ha}^{-1}\right)\end{array}$ & $\begin{array}{l}\text { N-uptake } \\
\left(\mathrm{kg} \mathrm{ha}^{-1}\right)\end{array}$ & $\begin{array}{l}\text { S-uptake } \\
\left(\mathrm{kg} \mathrm{ha}^{-1}\right)\end{array}$ \\
\hline \multirow[t]{5}{*}{$\mathrm{Se}_{0}{ }^{* 1} \mathrm{Se}_{0}{ }^{* 2}$} & $\mathrm{C}$ & $2.3 \pm 0.4^{\mathrm{c}}$ & $8 \pm 2.7^{\mathrm{a}}$ & $18 \pm 9.9^{\mathrm{a}}$ & $19 \pm 5.1^{b}$ & $4 \pm 0.8^{\mathrm{c}}$ \\
\hline & IR & $2.6 \pm 0.5^{\mathrm{bc}}$ & $12 \pm 6.0^{\mathrm{a}}$ & $30 \pm 12.2^{\mathrm{a}}$ & $27 \pm 4.7^{\mathrm{a}}$ & $4 \pm 0.8^{\mathrm{c}}$ \\
\hline & FR & $3.2 \pm 0.2^{\mathrm{a}}$ & $9 \pm 0.3^{\mathrm{a}}$ & $28 \pm 0.6^{\mathrm{a}}$ & $36 \pm 2.8^{\mathrm{a}}$ & $7 \pm 0.7^{\mathrm{a}}$ \\
\hline & $\mathrm{HV}$ & $2.7 \pm 0.1^{\mathrm{b}}$ & $10 \pm 4.7^{\mathrm{a}}$ & $28 \pm 14.5^{\mathrm{a}}$ & $30 \pm 1.8^{\mathrm{ab}}$ & $5 \pm 0.4^{\mathrm{b}}$ \\
\hline & Average & $2.7 \pm 0.5^{\mathrm{A}}$ & $10 \pm 4.1^{\mathrm{C}}$ & $26 \pm 11.1^{\mathrm{B}}$ & $28 \pm 7.2^{\mathrm{A}}$ & $5 \pm 1.6^{\mathrm{A}}$ \\
\hline \multirow[t]{5}{*}{$\mathrm{Se}_{0} \mathrm{Se}_{10}$} & $\mathrm{C}$ & $2.2 \pm 0.2^{\mathrm{a}}$ & $30 \pm 8.4^{\mathrm{a}}$ & $66 \pm 15.9^{\mathrm{a}}$ & $18 \pm 1.5^{\mathrm{ab}}$ & $3 \pm 0.1^{\mathrm{b}}$ \\
\hline & IR & $2.8 \pm 0.2^{\mathrm{a}}$ & $31 \pm 5.8^{\mathrm{a}}$ & $85 \pm 16.5^{\mathrm{a}}$ & $29 \pm 2.8^{\mathrm{a}}$ & $4 \pm 0.1^{\mathrm{b}}$ \\
\hline & FR & $3.0 \pm 0.3^{\mathrm{a}}$ & $22 \pm 11.2^{\mathrm{a}}$ & $65 \pm 27.2^{\mathrm{a}}$ & $32 \pm 5.2^{\mathrm{ab}}$ & $7 \pm 0.4^{\mathrm{a}}$ \\
\hline & $\mathrm{HV}$ & $2.0 \pm 1.2^{\mathrm{a}}$ & $21 \pm 7.2$ & $41 \pm 29.0^{\mathrm{a}}$ & $21 \pm 13.1^{\mathrm{ab}}$ & $4 \pm 2.2^{\mathrm{b}}$ \\
\hline & Average & $2.5 \pm 0.7^{\mathrm{A}}$ & $26 \pm 8.7^{\mathrm{A}}$ & $64 \pm 26.1^{\mathrm{A}}$ & $25 \pm 8.8^{\mathrm{A}}$ & $5 \pm 1.8^{\mathrm{A}}$ \\
\hline \multirow[t]{5}{*}{$\mathrm{Se}_{10} \mathrm{Se}_{0}$} & $\mathrm{C}$ & $2.3 \pm 0.3^{\mathrm{a}}$ & $15 \pm 7.2^{\mathrm{ab}}$ & $35 \pm 19.0^{\mathrm{a}}$ & $19 \pm 2.3^{\mathrm{b}}$ & $4 \pm 0.4^{\mathrm{b}}$ \\
\hline & IR & $2.4 \pm 0.4^{\mathrm{a}}$ & $28 \pm 20.8^{\mathrm{a}}$ & $65 \pm 46.6^{\mathrm{a}}$ & $26 \pm 4.2^{\mathrm{a}}$ & $4 \pm 0.5^{\mathrm{b}}$ \\
\hline & FR & $2.8 \pm 0.2^{\mathrm{a}}$ & $8 \pm 2.9^{\mathrm{b}}$ & $23 \pm 7.9^{\mathrm{a}}$ & $30 \pm 3.2^{\mathrm{a}}$ & $6 \pm 1.5^{\mathrm{a}}$ \\
\hline & $\mathrm{HV}$ & $2.8 \pm 0.3^{\mathrm{a}}$ & $11 \pm 7.1^{\mathrm{b}}$ & $31 \pm 18.6^{\mathrm{a}}$ & $29 \pm 2.5^{\mathrm{a}}$ & $5 \pm 0.4^{\mathrm{a}}$ \\
\hline & Average & $2.6 \pm 0.3^{\mathrm{A}}$ & $16 \pm 13.0^{\mathrm{B}}$ & $38 \pm 29.5^{\mathrm{B}}$ & $26 \pm 5.2^{\mathrm{A}}$ & $5 \pm 1.3^{\mathrm{A}}$ \\
\hline \multirow[t]{5}{*}{$\mathrm{Se}_{10} \mathrm{Se}_{10}$} & $\mathrm{C}$ & $2.3 \pm 0.3^{\mathrm{c}}$ & $29 \pm 11.1^{\mathrm{a}}$ & $63 \pm 20.5^{\mathrm{a}}$ & $18 \pm 2.5^{\mathrm{c}}$ & $4 \pm 0.7^{\mathrm{c}}$ \\
\hline & IR & $2.4 \pm 0.3^{\mathrm{bc}}$ & $25 \pm 10.1^{\mathrm{a}}$ & $58 \pm 17.7^{\mathrm{a}}$ & $25 \pm 4.7^{\mathrm{b}}$ & $3 \pm 0.5^{\mathrm{c}}$ \\
\hline & FR & $2.9 \pm 0.3^{\mathrm{a}}$ & $28 \pm 10.4^{\mathrm{a}}$ & $79 \pm 28.1^{\mathrm{a}}$ & $30 \pm 3.6^{\mathrm{a}}$ & $6 \pm 0.8^{\mathrm{a}}$ \\
\hline & HV & $2.7 \pm 0.5^{\mathrm{ab}}$ & $33 \pm 5.7^{\mathrm{a}}$ & $88 \pm 9.7^{\mathrm{a}}$ & $30 \pm 5.3^{\mathrm{a}}$ & $5 \pm 0.9^{b}$ \\
\hline & Average & $2.6 \pm 0.4^{\mathrm{A}}$ & $29 \pm 9.0^{\mathrm{A}}$ & $72 \pm 21.8^{\mathrm{A}}$ & $26 \pm 6.5^{\mathrm{A}}$ & $5 \pm 1.3^{\mathrm{A}}$ \\
\hline
\end{tabular}

Where Se: selenium; S: sulphur; C: bare soil; IR: Italian ryegrass; FR: fodder radish; HV: hairy vetch

*1 Se fertilisation rates (0 or $\left.10 \mathrm{~g} \mathrm{Se} \mathrm{ha}^{-1}\right)$ applied at catch crops

*2 Se fertilisation rates ( 0 or $\left.10 \mathrm{~g} \mathrm{Se} \mathrm{ha}^{-1}\right)$ applied at onions

Mean values of the three catch crops and bare soil treatments in the same fertilisation treatment by different letters (a, b, c) are significantly different. Mean values for fertilisation treatment followed by different capital letters (A, B, C) are significantly different $(n=4)$

\section{Discussion}

Catch crops did not reduce soil water-extractable Se content, as Se uptake was only $0.3-3.0 \%$ of the total water-extractable Se content in the soil. However, the impact of catch crops on soil water-extractable Se content was different in Experiments II and III, which could be attributed to differences in precipitation between the two experimental years. The higher precipitation in 2008 (Fig. 1) after the establishment of the catch crops, compared to 2009, may have leached Se deeper into the soil profile before the catch crops established a deep root system. It is interesting to note that the soluble Se content in the $0.25-0.75$ $\mathrm{m}$ soil layer in autumn in Experiment II was higher under fodder radish and Italian ryegrass compared to the control. The differences in subsoil water soluble Se in the autumn between species in Experiment II may be due to the resulting vegetative biomass of the catch crops. Fodder radish and Italian ryegrass had higher vegetation biomass and potentially higher rates of water use than hairy vetch. Well established vegetation reduces the amount of the drainage water leaching through the soil profile and thereby the leaching of $\mathrm{Se}$ and other ions in the soil solution ( $\mathrm{Wu}$ et al. 1996). Nevertheless, under field conditions, the reduced Se loss in the period until mid November under fodder radish and Italian ryegrass could not reduce Se leaching during the remaining part of the winter season, when vegetation biomass was decreased. 
Selenium concentrations were higher in fodder radish both in Experiments II and III which may be attributed to the higher $\mathrm{S}$ demand by fodder radish. Selenate is taken up by plants through high affinity sulphate transporters as a consequence of the chemical similarity between $\mathrm{S}$ and Se. Several Brassica crops have been shown to accumulate high Se concentrations (White and Broadley 2009). Moreover, Brassica roots show faster and greater soil depth penetration rates and achieve a much higher root density in the subsoil than monocotyledonous catch crops and hairy vetch (ThorupKristensen 2001), these features allow them to take up Se and S from the deeper soil layers.

Although catch crops increased soluble $\mathrm{Se}$ concentrations in the subsoil in mid November this did not influence Se concentrations in the cash crops. Onions are a shallow rooted crop, with estimated root depth at harvest being less than 0.3 $\mathrm{m}$ (Thorup-Kristensen 2006) and catch crops decreased topsoil Se content in spring. As the content of Se in the catch crops was quite small compared to the amount of extractable Se in the topsoil layers, it is not surprising that the effects of catch crops on $\mathrm{Se}$ availability were dominated by factors other than $\mathrm{Se}$ release during catch crop decomposition. The higher Se concentrations in cabbages compared to onions may be caused by the deeper root growth of cabbages which increases their access to more soil $\mathrm{Se}$ in deeper soil layers. Early harvested cabbage types were found to have root depths of at least 1.1 $\mathrm{m}$ compared to the more shallow-rooted onions which reached only $0.3 \mathrm{~m}$ (Thorup-Kristensen 2006).

Previous studies have shown that incorporation of catch crops, crop residues and manure in the soil reduced the availability of native soil $\mathrm{Se}$ or the $\mathrm{Se}$ added through fertilisation (Ajwa et al. 1998; Stavridou et al. 2011). On the other hand, Falk Øgaard et al. (2006) have found that the addition of cattle manure together with selenate might increase Se concentrations in wheat grain. Our results did not show clear effect of the catch crops incorporation, only a non-significant reduction of Se uptake by onions following catch crops was found in Experiments I and II, whilst the results in Experiment III were inconsistent. Differences between the experiments on the effect of catch crops on Se uptake by onions may be ascribed to the difference in the organic matter incorporated in the soil. The severe winter in 2010 (Fig. 1) reduced catch crop biomass. The catch crops did not recover in spring and the amount of plant material incorporated in the field was lower than in the previous year. Johnsson (1991) found that increasing the organic matter content in the soil from $1.4 \%$ to $39 \%$ decreased Se uptake by wheat grain and rape. The decreased Se uptake by onions following catch crops indicated that Se immobilisation may have occurred when onions were grown without $\mathrm{Se}$ fertilisation. According to Hamdy and GisselNielsend (1976) the addition of undecomposed organic matter (e.g. wheat straw) increases the microbial activity and subsequently the production of Se volatile compounds.

The Se fertiliser recovery rate of $6-17 \%$ by the catch crops was similar to that reported in other field trials (Broadley et al. 2010; Stroud et al. 2010 b), whereas Se recovery by the onions was lower $(-0.3-4 \%)$ than catch crops Se recovery and differed between years. While the applied Se fertiliser represented only a small fraction of waterextractable $\mathrm{Se}$ in the soil, it increased Se concentrations both in catch crops and cash crops even when the recovery was low. Selenite concentrations in the topsoil are reported to account for $19-49 \%$ of the potassium dihydrogen phosphate extractable $\mathrm{Se}$ (Stroud et al. 2010a) whilst selenate was not detectable. In this study only water-extractable Se was measured, it is likely that selenite and organic Se were the predominant forms present in solution, which explains why the addition of $10 \mathrm{~g}$ selenate $\mathrm{ha}^{-1}$ to a soil already containing c. $100 \mathrm{~g} \mathrm{Se} \mathrm{ha}^{-1} \mathrm{had}$ such a strong effect. Plants absorb Se from the soil primarily as selenate and plant Se uptake is greater when plants are treated with selenate compared to selenite (Fordyce 2005; Sharma et al. 2010).

Although Se input from fodder radish in Experiment III was higher compared to Se input from Italian ryegrass, hairy vetch and bare soil, it did not influence Se uptake by onions. In Experiment II, S uptake by onions following fodder radish grown without $\mathrm{S}$ fertiliser was higher than $\mathrm{S}$ uptake by onions grown in the $\mathrm{S}$ fertilised bare soil. Therefore it is likely that the low Se uptake following fodder radish may have been caused by the higher $\mathrm{S}$ availability from fodder radish.This antagonistic interaction between $\mathrm{S}$ and Se for plant 
uptake has long been noted by researchers (Li et al. 2008; Stroud et al. 2010b; White et al. 2004; White et al. 2007). In Experiment II, S fertilisation decreased Se uptake by onions when Se fertilisation was applied. The S status of the plant regulates the expression of the high affinity sulfate transporter genes as high concentrations of sulfate decreases transcription and potentially decreases Se uptake by plants (Sors et al. 2005).

The findings that extractable sulphate in subsoil was lower under fodder radish than Italian ryegrass and bare soil are consistent with those of Eriksen and Thorup-Kristensen (2002), who showed that cruciferous catch crops substantially depleted the soil available sulphate pool. The higher $\mathrm{S}$ uptake by onions following fodder radish reflected differences in plant $\mathrm{S}$ availability in soil, as $\mathrm{S}$ concentrations were higher in fodder radish leading to increased $\mathrm{S}$ mineralisation during its decomposition. The high sulphate content in the topsoil under hairy vetch may be attributed to rhizosphere acidification typically observed with $\mathrm{N}_{2}$ fixing legumes, which could promote mobilisation of $\mathrm{S}$ in the soil (Andersen et al. 2007; Haynes 1983) and explain the higher S uptake by onions compared to bare soil.

\section{Conclusion}

Hypothesis 1 that the use of catch crops would reduce Se leaching over winter was not supported. Selenium uptake by catch crops was less than $1 \%$ of the total water soluble $\mathrm{Se}$ in the soil. With such low uptake, effects on soil Se dynamics will be limited, and other indirect catch crop effects on Se availability, uptake and leaching are likely to dominate. High rainfall in the early growth stage of the catch crop can increase Se losses to the deeper soil layers before plants are able to reduce the excess water drainage. As the overall $\mathrm{Se}$ recovery by the crops was low, special attention should be paid to the fate of residual $\mathrm{Se}$ in the soil. The incorporation of catch crops in the field appeared to reduce the recovery of the applied Se and its uptake by onions, which indicates immobilisation. The results showed that the Brassica crop fodder radish was able to take up much more Se from Se fertiliser and native soil Se than the other catch crops, but did not decrease Se content in the soil and subsequently Se leaching. However, fodder radish did not increase Se concentrations in the subsequent cash crops, probably due to its high $\mathrm{S}$ mineralisation, which may limit cash crop Se uptake in succeeding crops.

Open Access This article is distributed under the terms of the Creative Commons Attribution Noncommercial License which permits any noncommercial use, distribution, and reproduction in any medium, provided the original author(s) and source are credited.

\section{References}

Ajwa HA, Banuelos GS, Mayland HF (1998) Selenium uptake by plants from soils amended with inorganic and organic materials. J Environ Qual 27:1218-1227

Alfthan G, Wang D, Aro A, Soveri J (1995) The geochemistry of selenium in groundwaters in Finland. Sci Total Environ 162:93-103

Andersen MK, Hauggaard-Nielsen H, Høgh-Jensen H, Jensen ES (2007) Competition for and utilisation of sulfur in sole and intercrops of pea and barley. Nutr Cycl Agroecosys 77:143-153

Broadley MR, Alcock J, Alford J, Cartwright P, Foot I, Fairweather-Tait SJ, Hart DJ, Hurst R, Knott P, McGrath SP (2010) Selenium biofortification of high-yielding winter wheat (Triticum aestivum L.) by liquid or granular Se fertilisation. Plant Soil 332:5-18

EC Scientific Committe on Food (2003) Opinion of the scientific committee on food on the revision of reference values for nutrition labelling. Commission of the European Communities, Brussels

Eich-Greatorex S, Sogn TA, Falk Øgaard A, Aasen I (2007) Plant availability of inorganic and organic selenium fertiliser as influenced by soil organic matter content and pH. Nutr Cycl Agroecosys 79:221-231

Eriksen J, Thorup-Kristensen K (2002) The effect of catch crops on sulphate leaching and availability of $\mathrm{S}$ in the succeeding crop on sandy loam soil in Denmark. Agricult Ecosys Environ 90:247-254

Eriksen J, Thorup-Kristensen K, Askegaard M (2004) Plant availability of catch crop sulfur following spring incorporation. J Plant Nutr Soil Sci 167:609-615

Eurola MH, Ekholm PI, Ylinen ME, Varo PT, Koivistoinen PE (1991) Selenium in Finnish foods after beginning the use of selenate-supplemented fertilisers. J Sci Food Agric 56:57-70

Falk Øgaard A, Sogn TA, Eich-Greatorex S (2006) Effect of cattle manure on selenate and selenite retention in soil. Nutr Cycl Agroecosyst 76:39-48

Fordyce F 2005 Selenium deficiency and toxicity in the environment. In Essentials of Medical Geology: Impacts of the Natural Environment on Public Health. Eds. O Selinus, B Alloway, J A Centeno, R B Finkelman, R Fuge, U Lindh and P Smedley. pp. 373-415. Elsevier Academic Press, London 
Hamdy AA, Gissel-Nielsend G (1976) Fractionation of soil selenium. Z Pflanzenernaehr Bodenkd 6:697-703

Haynes RJ (1983) Soil acidification induced by leguminous crops. Grass Forage Sci 38:1-11

Johnsson L (1991) Selenium uptake by plants as a function of soil type, organic matter content and $\mathrm{pH}$. Plant Soil 133:57-64

Li HF, McGrath SP, Zhao FJ (2008) Selenium uptake, translocation and speciation in wheat supplied with selenate or selenite. New Phytol 178:92-102

Mayland HF, Gough LP and Stewart KC (1991) Selenium mobility in soils and its absorption, translocation, and metabolism in plants. Selenium in arid and semiarid environments, Western United States US Geol Sur Cir 1064:55-64

Moxon AL, Rhian M (1943) Selenium poisoning. Physiol Rev 23:305-337

Rayman MP (2008) Food-chain selenium and human health: emphasis on intake. Br J Nutr 100:254-268

Sharma S, Bansal A, Dhillon SK, Dhillon KS (2010) Comparative effects of selenate and selenite on growth and biochemical composition of rapeseed (Brassica napus L.). Plant Soil 329:339-348

Sors TG, Ellis DR, Salt DE (2005) Selenium uptake, translocation, assimilation and metabolic fate in plants. Photosynth Res 86:373-389

Stavridou E, Thorup-Kristensen K, Young S (2011) Assesment of selenium mineralization and availability from catch crops. Soil Use Manage doi:10.1111/j.1475-2743.2011.00343.x

Stroud JL, Broadley MR, Foot I, Fairweather-Tait SJ, Hart DJ, Hurst R, Knott P, Mowat H, Norman K, Scott P (2010a) Soil factors affecting selenium concentration in wheat grain and the fate and speciation of Se fertilisers applied to soil. Plant Soil 332:31-40

Stroud JL, Li HF, Lopez-Bellido FJ, Broadley MR, Foot I, Fairweather-Tait SJ, Hart DJ, Hurst R, Knott P, Mowat H (2010b) Impact of sulphur fertilisation on crop response to selenium fertilisation. Plant Soil 332:31-40
Terry N, Zayed AM, de Souza MP, Tarun AS (2000) Selenium in higher plants. Annu Rev Plant Physiol Plant Mol Biol 51:401-432

Thorup-Kristensen K (2001) Are differences in root growth of nitrogen catch crops important for their ability to reduce soil nitrate-N content, and how can this be measured? Plant Soil 230:185-195

Thorup-Kristensen K (2006) Root growth and nitrogen uptake of carrot, early cabbage, onion and lettuce following a range of green manures. Soil Use Manage 22:29-38

Thorup-Kristensen K, Magid J, Jensen LS (2003) Catch crops and green manures as biological tools in nitrogen management in temperate zones. Adv Agron 79:227-302

Wang D, Alfthan G, Aro A, Lahermo P, Väänänen P (1994) The impact of selenium fertilisation on the distribution of selenium in rivers in Finland. Agric Ecosyst Environ 50:133-149

White PJ, Broadley MR (2009) Biofortification of crops with seven mineral elements often lacking in human diets-iron, zinc, copper, calcium, magnesium, selenium and iodine. New Phytol 182:49-84

White PJ, Bowen HC, Parmaguru P, Fritz M, Spracklen WP, Spiby RE, Meacham MC, Mead A, Harriman M, Trueman LJ (2004) Interactions between selenium and sulphur nutrition in Arabidopsis thaliana. J Exp Bot 55:1927-1937

White P J, Broadley M R, Bowen H C and Johnson S E (2007) Selenium and its relationship with sulfur. In Sulfur in plants an ecological perspective. Eds. M J Hawkesford and L J de Kok. pp. 225-252. Dordrecht: Springer, The Netherlands

Wu L, Mantgem PJ, Guo X (1996) Effects of forage plant and field legume species on soil selenium redistribution, leaching, and bioextraction in soils contaminated by agricultural drain water sediment. Arch Environ Contam Toxicol 31:329-338 